\title{
Høna, egget og forskjellene
}

Med utgangspunkt i nær 650000 nordmenn født i 1960-årene og data fra Folke- og boligtellingen og Reseptregisteret har Vidar Hjellvik og medarbeidere i dette nummer av Tidsskriftet kartlagt sammenhenger mellom utdanning og bruk av reseptbelagte legemidler (1). Resultatet er forskjellig fra det jeg ville ha gjettet meg til: Kort utdanning assosieres med mer legemiddelbruk både når det gjelder antall utleveringer, antall legemidler, antall definerte døgndoser (DDD) og kostnader. Forskjellene er også overraskende store - gjennomsnittlige kostnader og antall definerte døgndoser øker med en faktor på 2,5-3 fra høyeste (forsker) til laveste (grunnskole) utdanningsnivå.

Fenomenet ses for de fleste legemiddelgruppene. De med grunnskoleutdanning bruker mer av både lipidsenkende midler (hvor statinene dominerer), diuretika, antidepressiver, syrehemmende midler (hvor protonpumpehemmerne dominerer), betablokkere, ACE-hemmere og angiotensin-2-reseptorantagonister, sovemidler, antitrombotiske midler og - men her begynner forskjellen å bli liten - opioider enn de med mer enn ti års skolegang. Til sammenlikning er det bare noen få legemiddelgrupper som har sitt største relative pasientgrunnlag hos dem med lengre utdanning, og her er forskjellene små (1). Det er spesielt interessant at de korttidsutdannedes legemiddelbruk også gjelder dyre medikamenter: Den årlige listen over legemidler med høyest omsetning toppes av TNF-alfa-hemmere, midler mot obstruktiv lungesykdom og protonpumpehemmere (2), og bruken av disse legemiddelgruppene er ikke skjevfordelt i favør av dem med lengst utdanning - tvert imot (1).

En viktig begrensning ved denne type registerdata er at vi kun får informasjon om resepter som ekspederes på apotek. Dette er forskjellig fra hva som forskrives, og noe helt annet enn hva som egentlig brukes av legemidler. Når vi tar utgangspunkt i at mye forskrevet medisin ikke tas og at graden av etterlevelse ikke er relatert til utdanningslengde (3), sitter vi fremdeles igjen med store utdanningsrelaterte forskjeller i bruk av legemidler.

Min første reaksjon er lettelse - det er ikke noe i dette materialet som tyder på at lav utdanning hindrer tilgang til legemidler i Norge. De med lite skolegang bruker mer og flere legemidler enn de med et langt utdanningsløp, og overrepresentasjonen gjelder også legemidler i høye prisklasser. Den kanskje viktigste årsaken til dette ser vi i tabell 2 i Hjellvik og medarbeideres artikkel: Det offentlige tar brorparten av regningen for legemiddelforbruket (1). Det er positivt at blåreseptordningen virker, men det er bekymringsfullt at dette eneste gjenværende virkemidlet for nasjonal styring av legemiddelbruken ikke reguleres bedre. Blåreseptordningen skal favne godt dokumenterte og kostnadseffektive legemidler som er i langtidsbruk ved alvorlige sykdommer/risikofaktorer, men vi ser stadig eksempler på at disse kravene (og spesielt effektivitetskravene) forvitrer i møtet med forskjellige pressgrupper. Helsemyndighetenes vektlegging av farmakoøkonomisk modellering og prisregulering skjer på bekostning av en helhetlig tilnærming som i større grad burde ivareta nytte- og sikkerhetsaspektene tilknyttet legemiddelbruk. Blåreseptordningen burde i større grad vært innrettet mot velprøvde og godt dokumenterte midler med lang fartstid (4) og dessuten vært brukt aktivt for å hindre utgiftsøkninger på grunn av «me too»-midler (5).
Hva er årsaken til de utdanningsrelaterte forskjellene i legemiddelbruk? En av mine gamle kolleger fra et postdoktoropphold i New York i slutten av 1980-årene pleide å si at «Life is like a shit sandwich: The more bread you have, the less shit you have to eat.» Med direkte og visceral språkbruk, som for øvrig kjennetegner byens innbyggere, avspeiler munnhellet den velkjente erkjennelsen av at penger medfører makt, mestring og et godt liv. Nå er det imidlertid ikke alltid slik at lang utdanning er det samme som god økonomi, eller at mangel på utdanning leder til fattigdom. Det er kanskje ikke engang slik at lang utdanning betyr god helse. Alle som har kvalifisert seg som forsker, vil sikkert også nikke gjenkjennende til visdomsordene om at «Den som øker sin kunnskap, øker sin smerte» (6). Hjellvik og medarbeidere antyder underliggende sosiale ulikheter i helse, men avstår klokelig fra å trekke bastante konklusjoner fra funnene - utover det grunnleggende at utdanningslengde er inverst assosiert med legemiddelforbruk. De spekulerer imidlertid litt rundt sine funn, og det er fristende å lobbe enda et poeng inn i diskusjonen:

Mye av legemiddelforbruket, også der utdanningsgradienten er stor, gjelder midler som brukes profylaktisk, slik som statiner, antihypertensiver og antitrombotiske midler. Hvis vi legger til grunn at noen av de risikofaktorene som begrunner bruk av disse midlene (forhøyet kolesterolnivå, hypertensjon m.m.) ikke er spesielt skjevfordelt $\mathrm{i}$ befolkningen, kan dette bety at de med lav utdanning $\mathrm{i}$ størst grad etterkommer helsemyndighetenes og legemiddelindustriens anbefalinger om legemiddelbruk som veien til et langt liv med god helse. Motsvarende er de langtidsutdannede mer uregjerlige eller, som Hjellvik og medarbeidere også er inne på, mer skeptiske og kanskje til og med mer realistiske i sin oppfatning av legemidlenes yteevne og helseeffekter. Det er nærliggende å tenke på en tidligere leder i programmet som for kort tid siden gikk ut offentlig og sa at «Personlig ville jeg ikke ha gått til mammografiscreening» (7), og en framifrå kardiologkollega (som skal få lov til å være anonym) som ikke vil kjenne til sitt eget serum-kolesterolnivå. I så måte er funnene kanskje også uttrykk for mangel på tillit mellom publikum og de som bestemmer?

\section{Lars Slørdal}

lars.slordal@ntnu.no

Lars Slørdal (f. 1955) er professor i farmakologi og overlege i bistilling ved Norges teknisk-naturvitenskapelige universitet/St. Olavs hospital. Forfatter har fylt ut ICMJE-skjemaet og oppgir ingen interessekonflikter.

\section{Litteratur}

1. Hjellvik V, Mahic M, Tverdal A. Utdanning og legemiddelbruk. Tidsskr Nor Legeforen 2012; 132: $2166-70$

2. Legemiddelindustrien. Tall og fakta 2012. www.Imi.no/tall-og-fakta [1.9.2012] 3. Hov I, Bjartnes M, Slørdal L et al. Tas legemidler som foreskrevet? Tidsskr Nor Legeforen 2012; 132: 418-22

4. Rygnestad T, Slørdal L. Er det nyeste alltid det beste? Tidsskr Nor Legeforen 2008; $128: 680$

5. Light DW, Lexchin JR. Pharmaceutical research and development: what do we get for all that money? BMJ 2012: 345: e4348.

Bibelen. Fork 1,18.

7. Heggelund $G \AA \AA$. - Jeg ville ikke ha screenet meg. www.dagensmedisin.no/ nyheter/--jeg-ville-ikke-ha-screenet-meg (1.9.2012). 